\title{
Economic Diversification in Nigeria: Any Role for Solid Mineral Development?
}

\author{
Olumide .S. Ayodele, PhD \\ Senior Lecturer, Department of Economics \\ University of Calabar, Calabar, Nigeria. \\ Akongwale, Sabastine \\ (Corresponding Author) \\ Email: saba.akongwale@googlemail.com \\ Udefuna Patrick Nnadozie \\ National Institute for Legislative Studies \\ National Assembly, Abuja - Nigeria
}

Doi:10.5901/mjss.2013.v4n6p691

\begin{abstract}
For over four decades, the Nigerian economy has mostly depended on proceeds from the sale of crude oil. This is at the expense of other sectors such as solid minerals and agriculture that hitherto, contributed significantly to the economy of Nigeria. Employing both qualitative and quantitative analysis, this paper shows that the solid mineral sector in Nigeria has the potential to contribute immensely to the economy of Nigeria. Specifically, the paper reveals that the development of the solid mineral sector could help to combat poverty in Nigeria via job creation; especially, given its forward linkage with other sectors of the economy. Most importantly, it could help alleviate some of the problems associated with "enclave" nature of the Nigerian economy that has for too long being vulnerable to fluctuations in global oil prices. To realize these potentials, the paper highlights the need for a strengthening of Nigeria's existing solid mineral development policy. It also points out the need for the government to create an enabling environment for the private sector to take the lead in the sector.
\end{abstract}

Key Words: Diversification, Resource Curse, Enclave Economy

JEL Classifications: Q24, Q32, Q33, Q38,

\section{Background: Structure of the Nigerian Economy}

Nigeria is blessed with a huge endowment of solid minerals widely distributed across the different geographical belts of the country. Prior to the early crude oil booms of the 1970s and the 1980's, solid mineral such as Coal, Tin and Columbite to mention but a few, contributed immensely to the economy of Nigeria. Coal was the major source of power generation as well the main source of power for the railway transportation systems. Nigeria was the largest producer of Columbite at one point. In the prevailing times, the earnings from solid minerals were used to develop roads, education, hospitals and in fact develop the petroleum industry.

The decline of the solid minerals industry started with the discovery of crude oil and to an extent, that Nigeria became a mono product economy and hence vulnerable to international oil politics and its repercussions. The domineering role of oil did not allow past governments to attend to global challenges that evolved in the development of solid minerals. No doubt, the petrodollar from these oil booms led to the neglect of these huge economic potential. This made Nigeria to experience the "Dutch disease" reflected by an appreciating exchange rate, subsidise imports while discouraging non-oil exports; which in Nigeria's case includes the solid mineral sector which hitherto the discovery of crude oil was a major contributor to economic growth ${ }^{1}$. Also, the level of investment in solid mineral exploration and development is far below that of the oil and gas industry that has seen an exponential growth since Nigeria became a petro state.

1 See for example Sala-i-Martin and Subramanian (2003)

Sachs and Warner 1995 
With the return to democracy in 1999, and the launching of various economic reform programmes (ERPs), diversification of the economy from a mono- product one with all its attendant vulnerabilities has being at the core of government's economic policy thrust. Hence, there was the launch of the National Minerals and Metal Policy which is also part of the government's vision 202020 goal to diversify Nigeria's major source of revenue from oil to about 50 percent by the year 2020.No doubt, the neglect of the minerals industry led to disorder in the minefields with attendant problems such as the presence of illegal miners whose activities are characterized by inefficient mining, illegal trading of highly priced minerals, severe ecological degradation, spread of ailments from metals such as lead poisoning; diseases and huge loss of revenue to the government through smuggling.

\subsection{Significance of the Study to existing Solid Mineral Development Policy in Nigeria}

Given the over dependence of the Nigerian economy on volatile global of oil prices, coupled with the neglect of other sectors that had hitherto sustained the Nigerian economy, it has now become imperative for the Nigerian economy to be diversified. Predicated on this scenario (volatility of oil prices), the economy will be subjected to fiscal shocks with attendant problems such as fiscal deficits. Also, there is a need to manage macroeconomic stability and pro-cyclical government expenditure pattern by improving non-oil growth performance and saving Nigeria's oil revenues for future use. Similarly, the resurgence of mineral commodity prices with global increase in exploration for solid commodities necessitates the development of a policy framework that will ensure the efficient and effective utilization of the nation's mineral resources. Thus, the ministry of solid minerals main policy objective which is the increase mineral production and value addition by focusing on exploration, exploitation, processing utilization and marketing of mineral resources of the country needs to be strengthened to achieve these policy objectives.

\subsection{Outline}

The first section of the paper provides a general introduction, and sets out the significance cum objectives of the policy paper. It also highlights the methodology to be employed to address the key issues. In the second section, we will be examining the structure of the Nigerian economy with a view to X-raying the need for diversification of the economy towards solid mineral development. Section three will be a brief review of the Nigerian solid mineral development policy. In section four we will be X-raying the impact of the contribution of the solid mineral sector to the economic development of the Nigeria. Section five will focus on the opportunities and potentials for solid mineral development in Nigeria as well as the value addition chain. The policy paper concludes by providing a way forward in the solid mineral sector in Nigeria.

\section{Structure of the Nigerian Economy: The Need for Solid Mineral Development as a Means of Diversification.}

Nigeria is Africa's top oil exporter, and the world's tenth largest oil producing country. It has realized over US $\$ 600$ billion in oil revenues since 1960, a figure greater than the resources used by the Marshall Plan in rebuilding Europe after World War Two ${ }^{2}$ and is currently the $8^{\text {th }}$ highest net oil exporter in the world. Nigeria's economy is heavily dependent on natural resources: oil and gas constitutes circa 80 percent or more of government revenues in some years ${ }^{3}$.

\footnotetext{
2 See Watts, Kemedi and Okonta (2004).

${ }^{3}$ See figure 1 and 2 below.
} 
Figure 1. Oil Revenue as a Percentage of Total Government Revenue in Nigeria

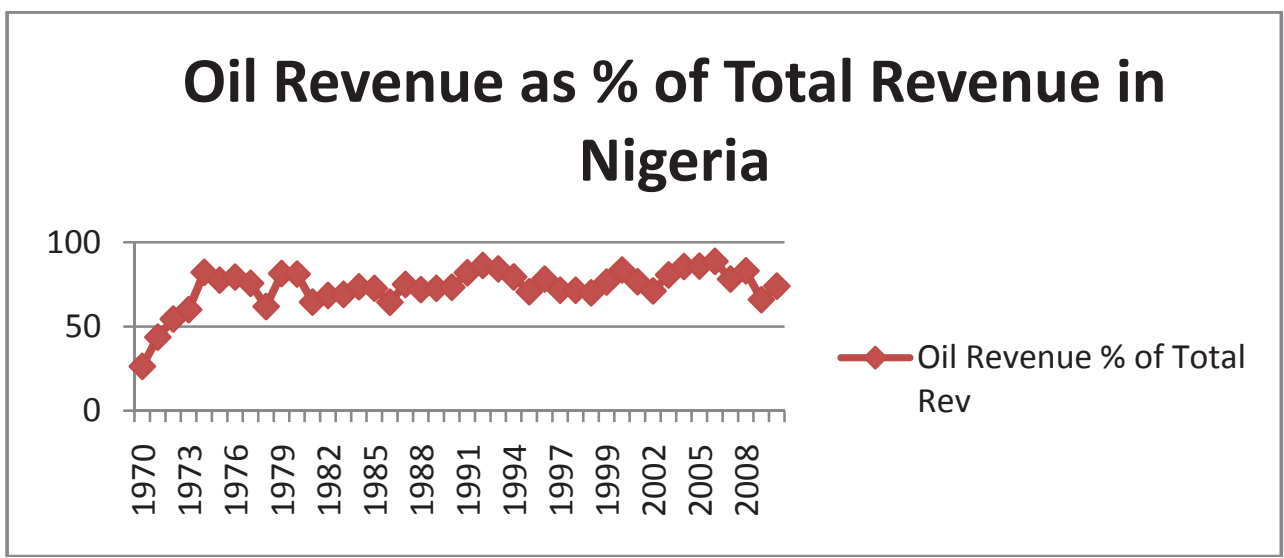

Source: CBN Annual Statistical Bulletin 2010

The 1970's ushered Nigeria into a new era of prosperity, enjoying a bounteous oil windfall due to the increase in global oil prices precipitated by the Arab Israeli crisis. The negative effects of this oil windfall were reflected in exchange rate appreciation, import subsidies, and a decline in vital sectors such as Agriculture and manufacturing ${ }^{4}$-in the case of Nigeria, the solid mineral sector also suffered as earlier pointed out. However, the profligacy and waste that accompanied Nigeria's elevation to the status of an oil-rich petro state experienced a hitch at the start of the next decade. The 1980's oil glut forced a sharp drop in oil receipts, and consequently economic growth. Confronted with corruption, capital flight and mounting foreign debt, Nigeria, was left with no option but to undergo structural reforms such as the IMF's Structural Adjustment Programmes (SAP) to address the distortions caused by oil dependence. With the return to democratic rule in 1999 , a series of macroeconomic and fiscal reforms have been undertaken, most of them having economic diversification as a core element. It was also able to secure a debt buy back deal from the Paris club in 2006 which reduced the external debt even though her current domestic debt of circa $\$ 34$ billion is a threshold that is perturbing.

The public expenditure pattern in Nigeria throughout this period mirrors the trend in global oil prices and consequently oil revenues in Nigeria. The graph below (Fig.2) confirms the procyclical nature of the of the public expenditure pattern in Nigeria. It is evident from the graph that changes in oil revenue leads total government expenditure. Figure 2 below shows that changes in oil revenue have always led changes in total government expenditure, while total government expenditure lags. The implication here is that fiscal policies in Nigeria are always very vulnerable to global oil prices leading to a dip in government revenue and consequently government expenditure in the years of decline in oil revenues and vice versa. 
Figure 2: Procyclical Public Expenditure Pattern in Nigeria

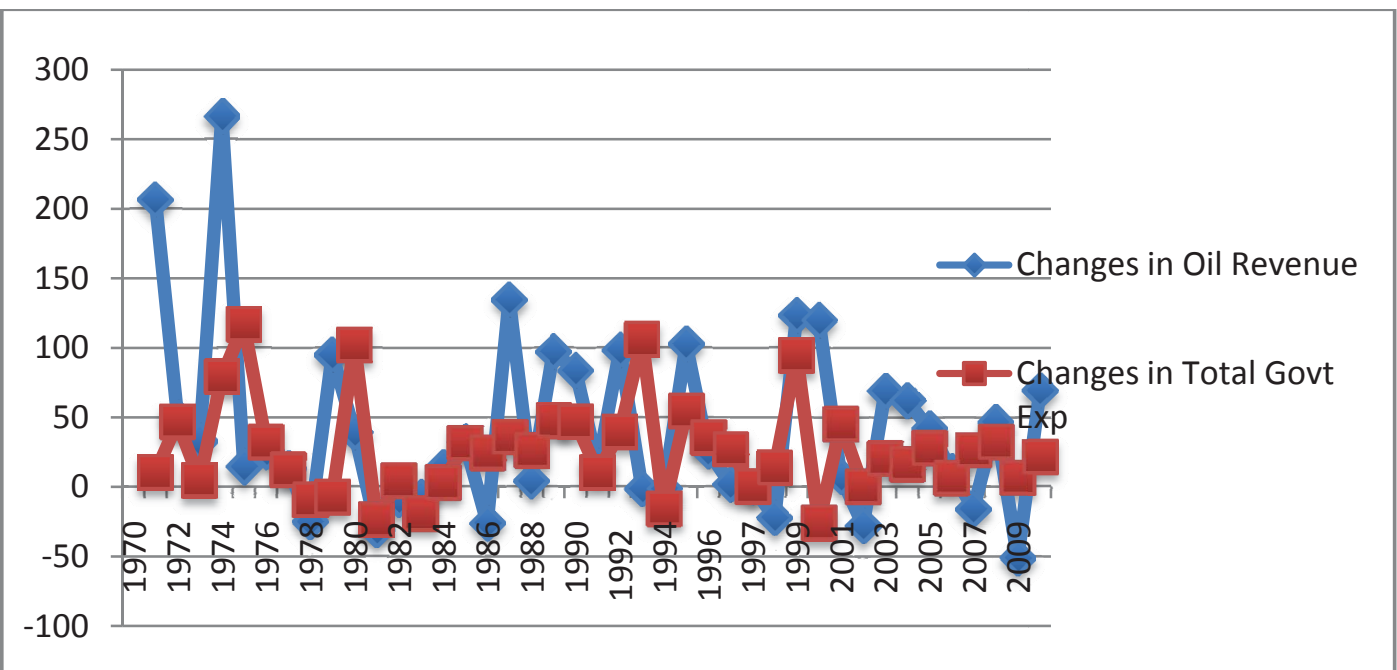

Source: CBN Annual Statistical Bulletin (2010)

In the same vein, figure three shows that oil changes in oil revenue as a percentage of total federal revenue has positive (increasing) during most periods of oil booms (1973-1976,1980-1981, 1990-1991 and in the 2000s. On the contrary changes in non -oil revenue during these periods was mostly negative (decline). This is a perfect reflection of the neglect of other key (non-diversification of the economy).

Figure 3: Changes in Oil Revenue vs. Changes in Non-Oil Revenue in Nigeria

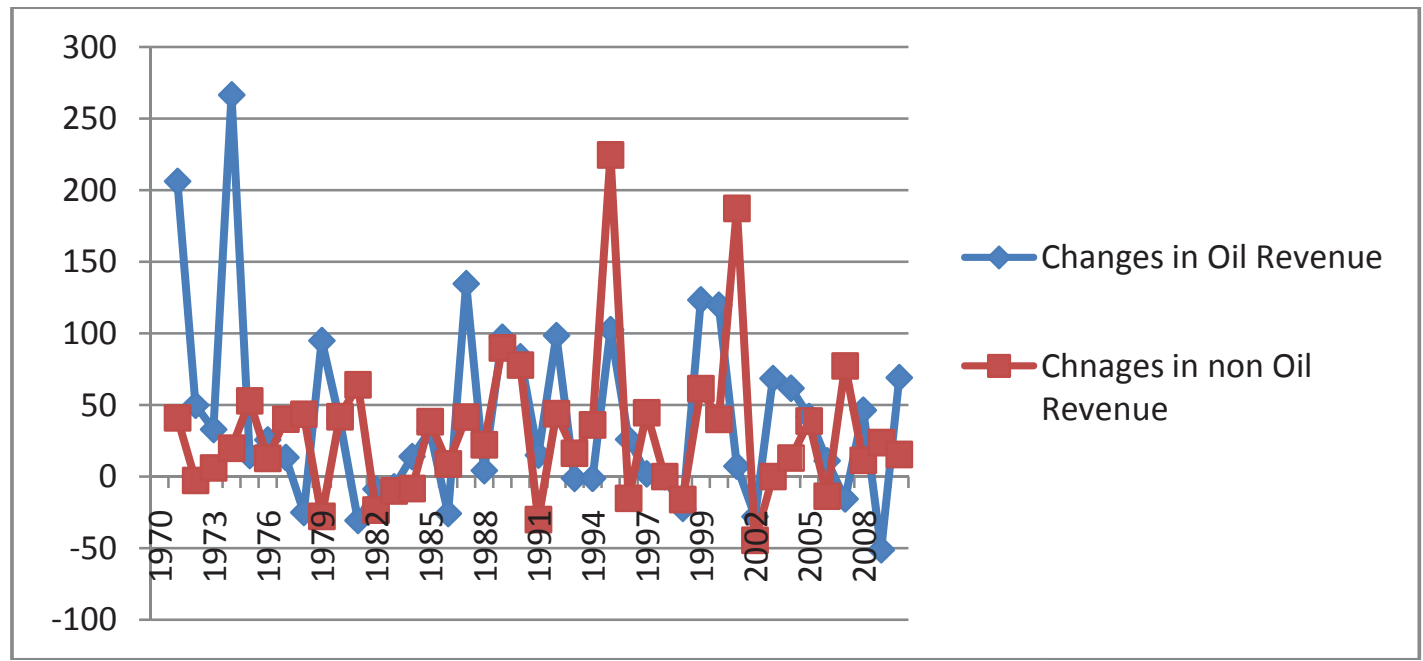

Source: CBN Annual Statistical Bulletin (2010)

Despite the huge economic potentials in Nigeria, it has largely failed to live up to the ambitious growth and developmental projections that followed the first oil boom in the 1970s. In 2010, it was ranked $142^{\text {nd }}$ out of 169 countries by the United Nations Human Development Index. Furthermore, up to $50 \%$ of Nigerians are considered to be 'poor' - surviving below 
the national poverty line. ${ }^{5}$ Nigeria has evidently grappled with resource curse (paradox of plenty). The term 'resource curse' refers to the paradox that countries with an abundance of natural resources such as fossil fuels tend to have lower economic growth and poor development outcomes, in contrast to those countries with fewer natural resources. There are various empirical arguments in support of the paradox of plenty. The negative impacts of resource abundance include; a decline in the competitiveness of other economic sectors (caused by over appreciation of the real exchange rate, volatility of revenues from the natural resource sector due to exposure to global commodity market swings, government mismanagement of resource revenues, weak, ineffectual and corrupt institutions.

\section{Section 3: A Critical Review of the Nigerian Solid Mineral Development Policy.}

In 2007, Nigeria launched a solid mineral development policy which is fundamentally hinged on the Minerals and Mining Act of 2007. However, they were earlier efforts towards the development of the solid mineral sector albeit with very little success, some of these include:

i. $\quad$ The New National Policy on Solid Mineral development, 1998

ii. The enactment of the Minerals and Mining Act of 1999

iii. Development of the Seven Year Strategic Action Plan for Solid mineral development in Nigeria, $(2002,2009)$;

iv. Establishment of the Nigerian Geological Survey Agency

V. Establishment of Sustainable management of Mineral Resources Project- a World Bank Assisted Programme.

vi. Establishment of the Mines Environment Compliance Department to ensure best international practices

vii. Establishment of the Artisanal and Small Scale Mining Department as a focused department for small entrepreneurs and local content.

Given the role played by the solid mineral sector prior to the discovery of oil, it is apparent that solid minerals have the capacity to contribute immensely to the economic development of Nigeria as in the pre-independence years. Previous solid mineral development policy decisions could not produce the desired outcome for which they were adopted, and the current solid mineral development policy does not seem to be adding much to the GDP of the economy. Thus, for the sector to develop beyond its current abysmal level, a critical evaluation cum reform of the policy is imperative. This could develop further the enabling environment for the sector to flourish and achieve its primary objective.

\section{Rationale for a Sound Solid Mineral Development Policy}

In the last two decades, the demand for mineral commodities has being on the rise. This is partly attributable to the emerging economies of Asia and Latin America as well as the bourgeoning global population. Also, in the intervening time, Nigeria's mineral potential is not fully exploited owing to over reliance on oil proceeds which is vulnerable to external shocks in the global oil price. Thus, the primary objective of the current government policy on sold mineral development is to take maximum advantage of the increase international commodity prices and the global resurgence of exploration activities, coupled with the potential benefits to the Nigerian economy as a whole, that has for too long depended mostly on oil revenues -Hence the need for diversifying the economy from over reliance on oil.

\section{The Objective of the Policy Include:}

i. Achieve sustainable increase in GDP contribution by the minerals sector;

ii. Generate quality Geoscience data;

iii. Establish transparent licensing regime;

iv. Formalize artisanal and small scale mining operators

v. Poverty eradication through ASM operations;

vi. Employment generations;

vii. Wealth creation through value addition;

viii. Increase capacity of mineral based industries

\footnotetext{
${ }^{5}$ The most recent statistics on poverty and income inequality in Nigeria are provided by the National Bureau of Statistics, based on projections from the 2004 Living Standards Measurement Survey.
} 
ix. Attract private investment capital

\section{Section Four: Solid Minerals and the Nigerian Economy}

Figure 4: Nigeria - Solid Minerals and Allied Sectors as a Percentage of GDP 2000-2010

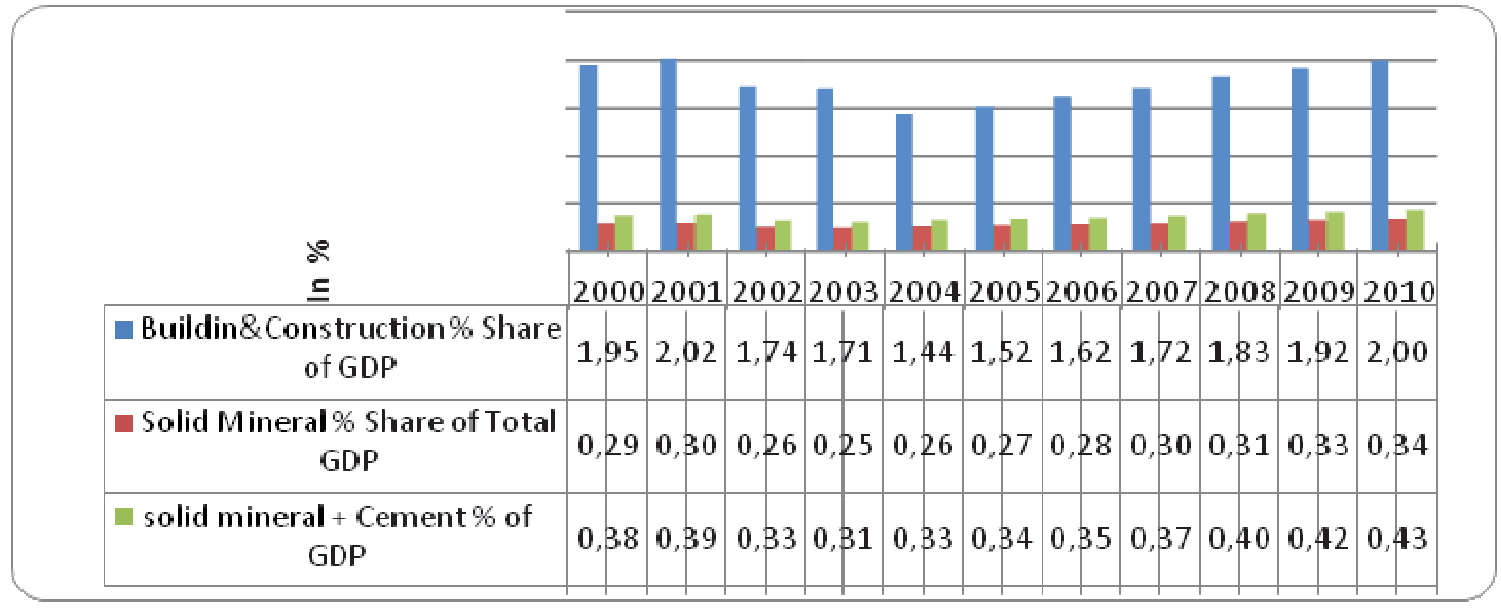

Source: 2011, National Bureau of Statistics Socio Economic Survey.

When taken in abstraction, the data above suggests that solid mineral as a sector contributes less than $1 \%$ of Nigeria's GDP between the period of 2000 and 2010. Interestingly, this may not be the case when a comprehensive forward and backward linkage analysis of the solid mineral sector and other sectors that are dependent on it for raw material is undertaken. The statistics shows that as solid mineral contribution to GDP increases, Building and construction contribution to GDP increases as well, thereby connoting a positive correlation between the two sub sectors.

\section{Growth Rate of Solid Mineral Sector Vis-a- Vis the Entire Economy}

Figure 5 GDP Growth Rate vs. Growth Rate of Solid Mineral Contribution to GDP

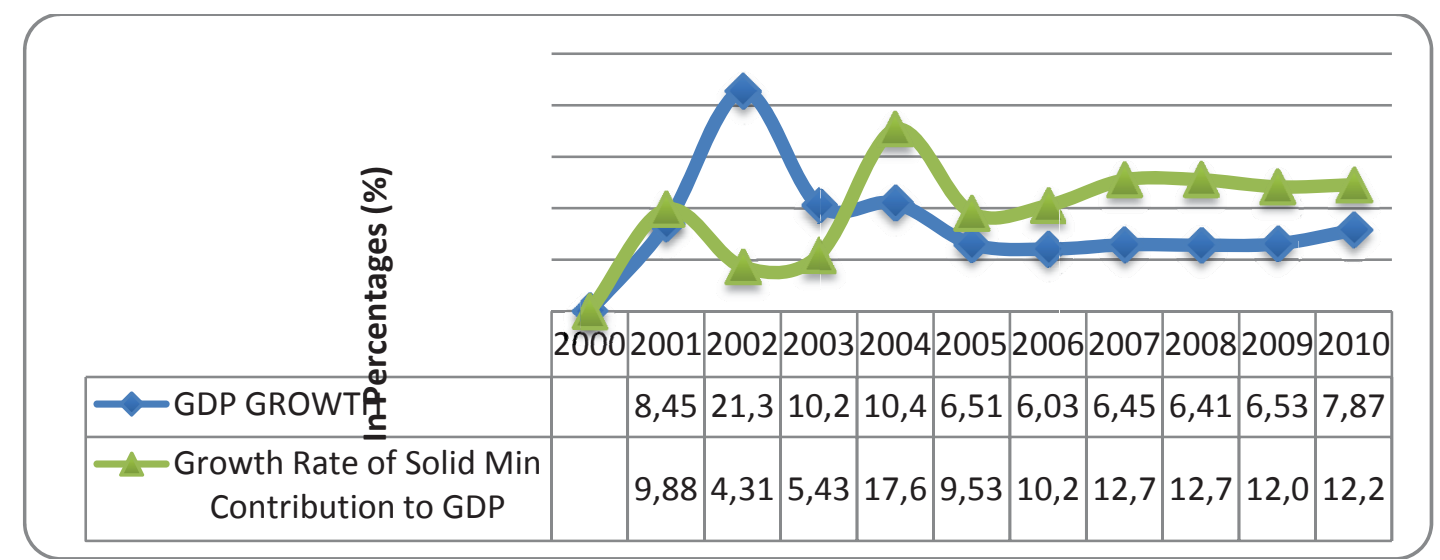

Source: 2011, National Bureau of Statistics Socio Economic Survey. 
A cursory examination of the data from figure 5 above, shows that from 2006 to 2011, while GDP growth rate stood at single digits between (6.03-7.87\%), the growth rate of solid mineral contribution to GDP's was double digit (10.2812.28\%). This is a reflection of the fact that Solid mineral sector is growing faster than the entire economy. This implies that with the right policy in place, the solid mineral sector has the potential to contribute immensely more than it is currently doing towards government revenue, provide jobs in allied sectors as well as consequently helping to alleviate poverty in Nigeria.

\section{Solid Mineral Contribution to Employment and Poverty Alleviation}

Due to the dearth of statistics on employment, especially intra sectoral employment in Nigeria, it might be difficult to ascertain the exact figure of those employed in these sector that rely mostly on the solid minerals sectors for raw materials; especially, smaller retail businesses whose businesses rely heavily on the level of business activities in the main sector. Interestingly, most of these businesses are registered businesses such as restaurants and retail shops, thereby increasing the tax base and consequently revenue for the government. However the National Bureau of Statistics conducted a socio economic survey of some sectors of the economy, from which we can deduce the contributions of the solid mineral sector to job creation and the fight against poverty. However, it will suffice to point out that this figure does not necessarily include the numbers from self-employed small businesses that service these industries.

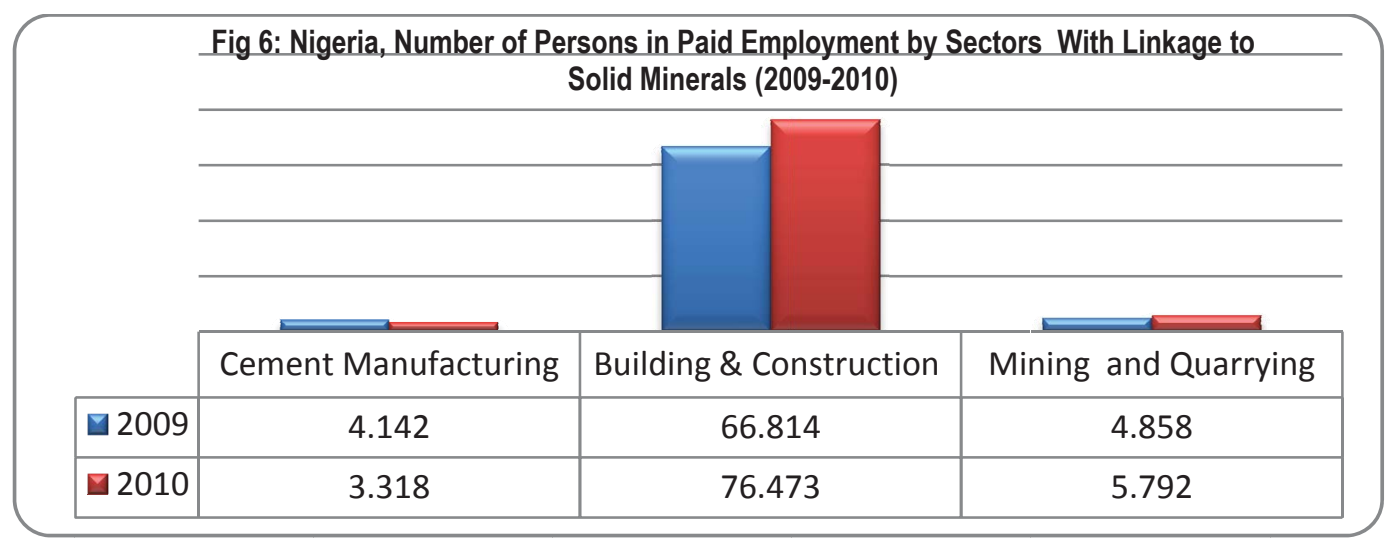

Source: 2011, National Bureau of Statistics Socio Economic Survey

Figure 7: Nigeria, Average Monthly Salary for Sectors with Linkage to Solid Minerals in Nigeria

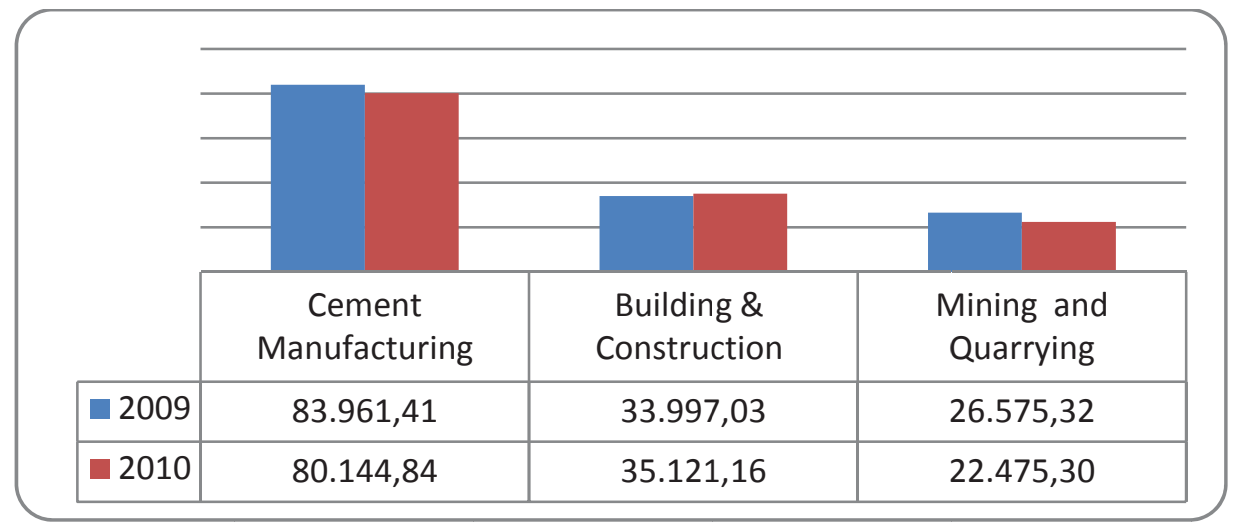

Source: 2011, National Bureau of Statistics Socio Economic Survey. 
Figure 8: Nigeria - Employment Structure (Cement and Manufacturing)

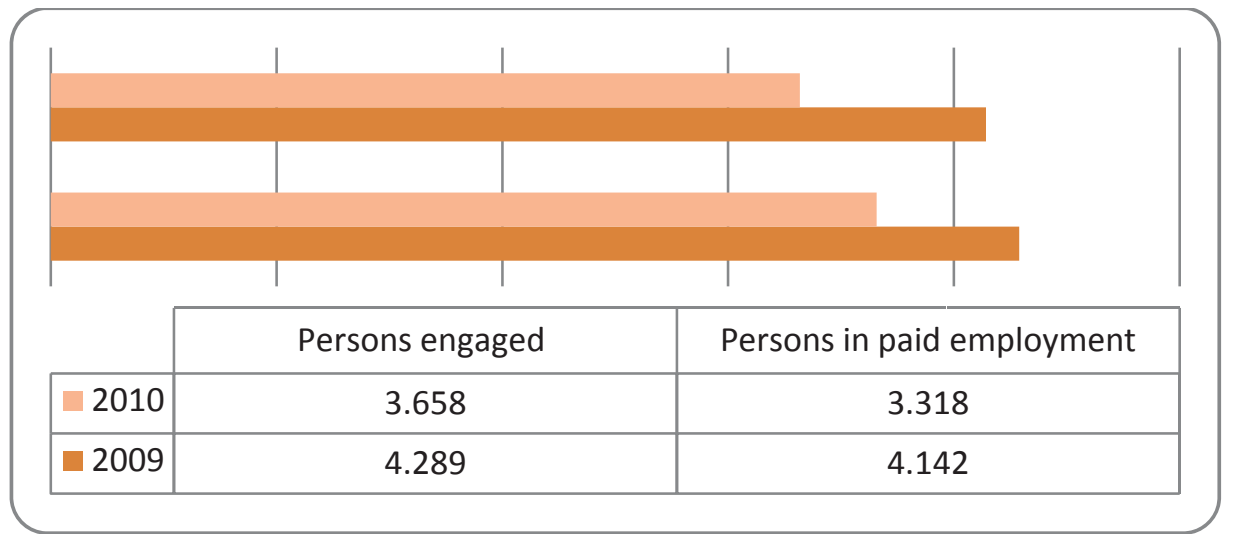

Source: 2011, National Bureau of Statistics Socio Economic Survey.

From figures 6-8, it can be seen that solid mineral sector as well as it allied sectors of cement manufacturing and building and construction contributes significantly towards job creation in Nigeria and thus reducing poverty. Building and construction recorded the highest number of people employed in the sub sector, with a most recent recording of 76,473 as at 2010 , followed by mining and quarrying and the cement manufacturing. As depicted in figure 4 above, the total spending for emoluments (wages and salaries) for the cement industry in Nigeria, stood at circa N4.17Billion in 2009 and 3.19billion in 2010 respectively. This is a significant figure and there is room for improvement.

Figure 9: Nigeria Employment Structure-Mining and Quarrying Sector

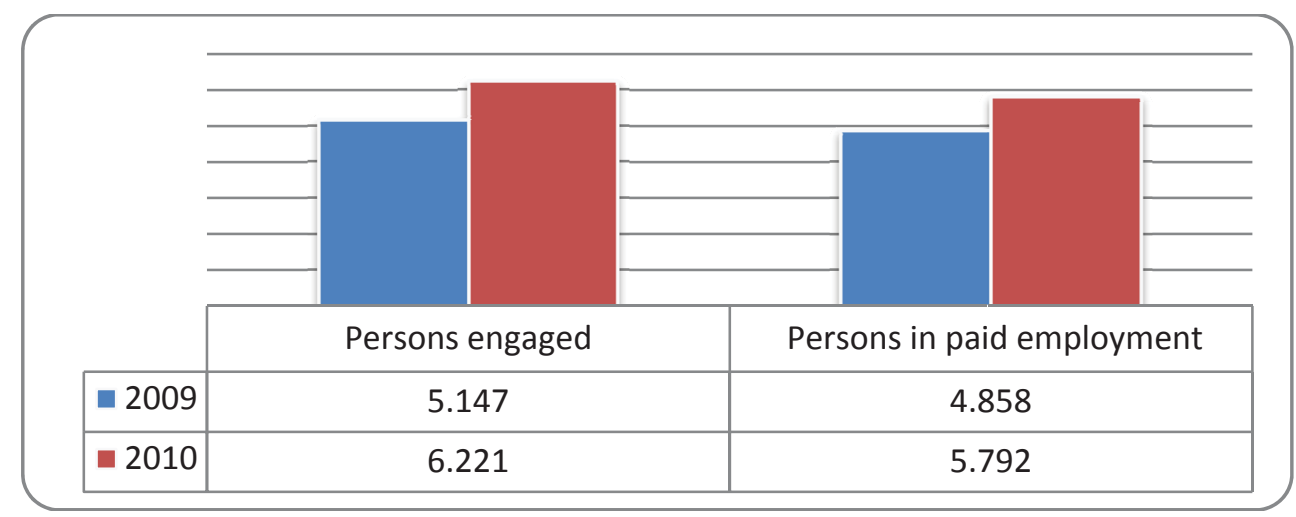

Source: 2011, National Bureau of Statistics Socio Economic Survey

The mining and quarry sub sector also contributes considerably to the economy, especially in terms of the amount it provides as wages to those engaged in it. Between 2009 and 2010 it experienced a close to $20 \%$ uptick in the number of persons employed formally in the sector, from 4,558 in 2009 to5,792 in 2010. Similarly, those engaged in the sector rose from 5,147 to 6,221 in 2010 (a net job gain in the sub sector). The total emolument increased marginally from N1.55 billion in 2009 to N1.56 billion in 2010. Again these figures refer to those engaged in employment in the sector and does not include the statistics of those employed in ancillary sectors and small businesses that provide services for the sector. 
Figure 10: Nigeria - Employment Structure (Building and Construction)

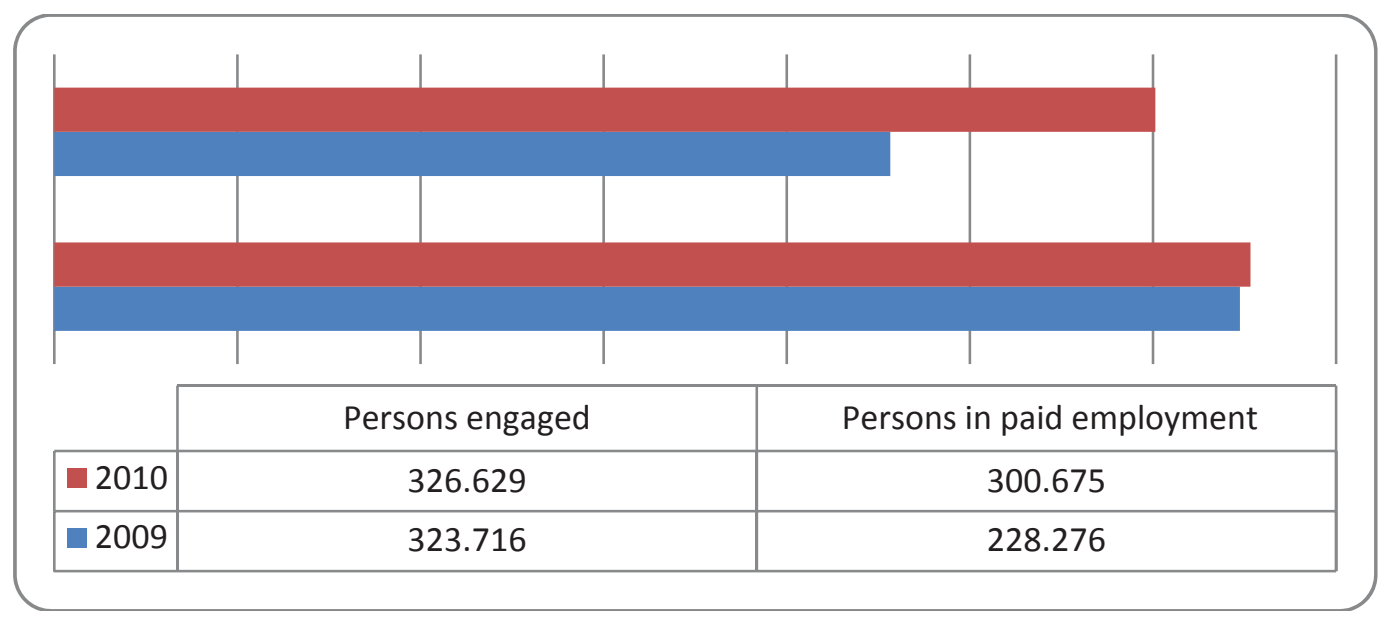

Source: 2011, National Bureau of Statistics Socio Economic Survey

One of the allied sub sectors of the solid mineral industry is the building and construction industry. As can be seen from the graph above, the number of persons employed and those engaged by this sector increased between 2009 and 2010(a net job gain in the sector). Based on the average salary for workers in this sector presented above, the total wage bill that accrued to workers in this sector rose from N27.26 billion in 2009 to N32.23 billion in 2010, a spike of over $20 \%$; couple with the increase in workers employed in the sector, this shows the ability of the sector to create jobs, expand the tax base for the government, thereby increasing government revenue and contribute to the welfare of the citizenry. Thus, any meaningful effort by the government on job creation and poverty alleviation should take into cognizance the potentials from this sub sector.

Table 1: Trends in Solid Mineral Production in Nigeria

\begin{tabular}{|c|c|c|c|c|c|}
\hline & \multicolumn{4}{|c|}{ Solid Mineral Production, 2002-2006 (000' Metric Tonnes) } & \multirow[b]{2}{*}{2006} \\
\hline & 2002 & 2003 & 2004 & 2005 & \\
\hline Barytes & $57,839.00$ & $63,622.90$ & $69,000.00$ & na & $30,010.56$ \\
\hline Cassiterite & $1,004.14$ & $1,134.00$ & $1,748.00$ & 100.00 & $1,817.88$ \\
\hline Feldspar & 468.00 & 514.80 & 982.00 & 268.50 & $1,021.28$ \\
\hline Kaolin & $52,352.00$ & $57,587.20$ & $92,875.00$ & 60.00 & $96,590.00$ \\
\hline Limestone & $11,414,926.81$ & $12,556,419.49$ & $14,693,090.90$ & $1,160,615.80$ & $15,280,814.54$ \\
\hline Marble & $34,053.70$ & $1,208,532.00$ & $1,140,117.00$ & $2,659.00$ & $1,185,721.68$ \\
\hline Tantalite & $3,886.00$ & $25,598.00$ & $23,801.00$ & na & $24,753.40$ \\
\hline Wolframite & na & 2.00 & na & na & $3,720.88$ \\
\hline
\end{tabular}

Source: Ministry of Solid Minerals as Cited on NBS(2010).

As pointed out earlier, Nigeria is blessed with numerous solid mineral resources. A Cursory look at table 1above reveals an upward growing trend in solid mineral production in Nigeria. Most of these minerals have a high price in the international market. Nigeria's production of Casserite increased by over 80\% between 2002 and 2006 (the last year of 
available data); the bulk of this increment in production levels came in 2006; from an abysmal 100 metric tons to about 1817 tons (shortly after the adoption of the national policy of solid minerals and steel). Other precious stones/metals such as feldspar, marble, kaolin Tantalite and Wolframite experienced an astronomical growth especially between 2005 and 2006, a reflection of the potential for solid mineral to contribute immensely to the Nigerian economy. Interestingly, limestone production -a major raw material for building and construction also grew by over $30 \%$ during this time; thus, leading to a growth in activities in the cement, building and construction as well as all allied industries in the immediate lead years.

\section{Solid Minerals \& Mining Sector's Impact on Related Sectors of the Nigerian Economy}

Following our earlier analysis, we have seen that in abstraction, the solid mineral sector's contribution to GDP has increased marginally to about $0.34 \%$ from less than $0.28 \%$ in 2005 . Also, the growth rate of the sector, even though unstable, shows that periods of high growth will impact positively on sectors such as building and construction, real estate and cement industry, that depend to some extent on the raw materials produced in the solid mineral and mining sector. This indirect and important role of the solid mineral and mining sector is very important since activities in the building, construction, real estate and cement industries are leading economic indicators. Specifically, the sectors are important to the overall economic growth and development as indicators such as housing starts are leading economic indicators, which give direction to the economy. In other words, the sustained growth in the sectors indicates an upswing in general economic activity, while a decline forecasts a fall in economic activity or a recession. The construction industry in particular is important for its multiplier effect because of the close relationships between this sector and others such as, transportation, building materials, agriculture, financial, etc.

However, the building, construction, cement and real estate industry accounts for only $2 \%$ of Nigeria's GDP despite their critical importance to the development process. One of the key challenges responsible for the low contribution of these sectors to GDP (and this also indirectly affect the solid mineral and mining sector) is the Land Use Act (introduced in 1978). The Act restricts the supply of urban land and forces developers to follow complex procedures to obtain building permits. According to the Act, the government is the owner of most of the country's land, which is held in trust on behalf of the people. Nonetheless, there have been attempts at reviewing the Act albeit with little success. Hence, the importance of land as shown in figure 1 means that the future growth of the solid mineral and mining sector will indirectly be affected by the review of the Land Use Act 1978.

Figure 11. The Significance of Land
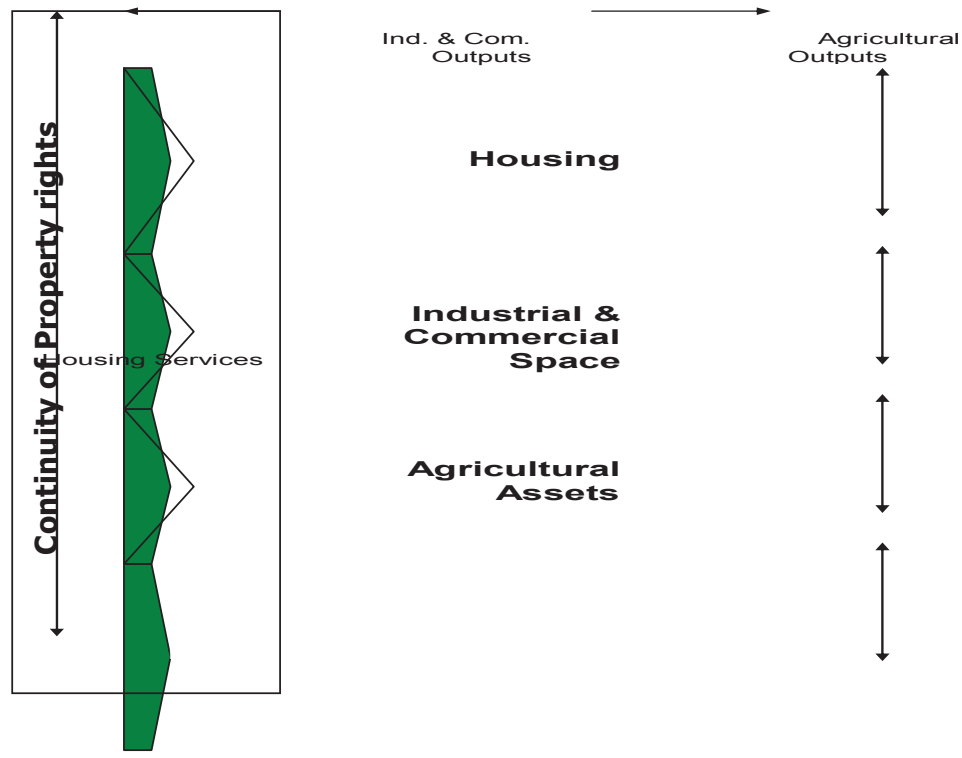
One more challenge facing the building, construction, cement and real estate sectors is that contractors working on government-owned projects frequently experience delayed payments. This slows activities in the sectors and indirectly the activities in the solid mineral and mining sector. The inference that can also be made from this is that with the bulk of the federal government budget going for recurrent expenditure, less of government money is available for capital expenditure which has direct impact on building and construction sectors, and therefore indirectly on the solid mineral and mining sectors. Also, even though only about $30 \%$ of the budget of the federal government is allocated for capital expenditure, the poor implementation of the budgets means that the $30 \%$ allocation is not even used judiciously. Consequently, we may argue that poor budget implementation indirectly hurts the solid minerals and mining sector because the building, construction and cement sectors that benefits from linkage with the solid mineral sector are directly hurt by poor budget implementation. This position is further explained from figure 2 that shows the value chain of the cement industry. We see that the cement industry inputs include raw materials from the solid mineral and mining sector such as coal, gypsum, copper, zinc, etc. Following from the raw materials stage in the cement value chain where the solid mineral and mining sector play a critical role, the processing, output and distribution stages of the chain means that the cement industry adds value to the overall economy through the activities of different players in the different stage of the value chain.

Figure 12: Value Chain of the Cement Industry

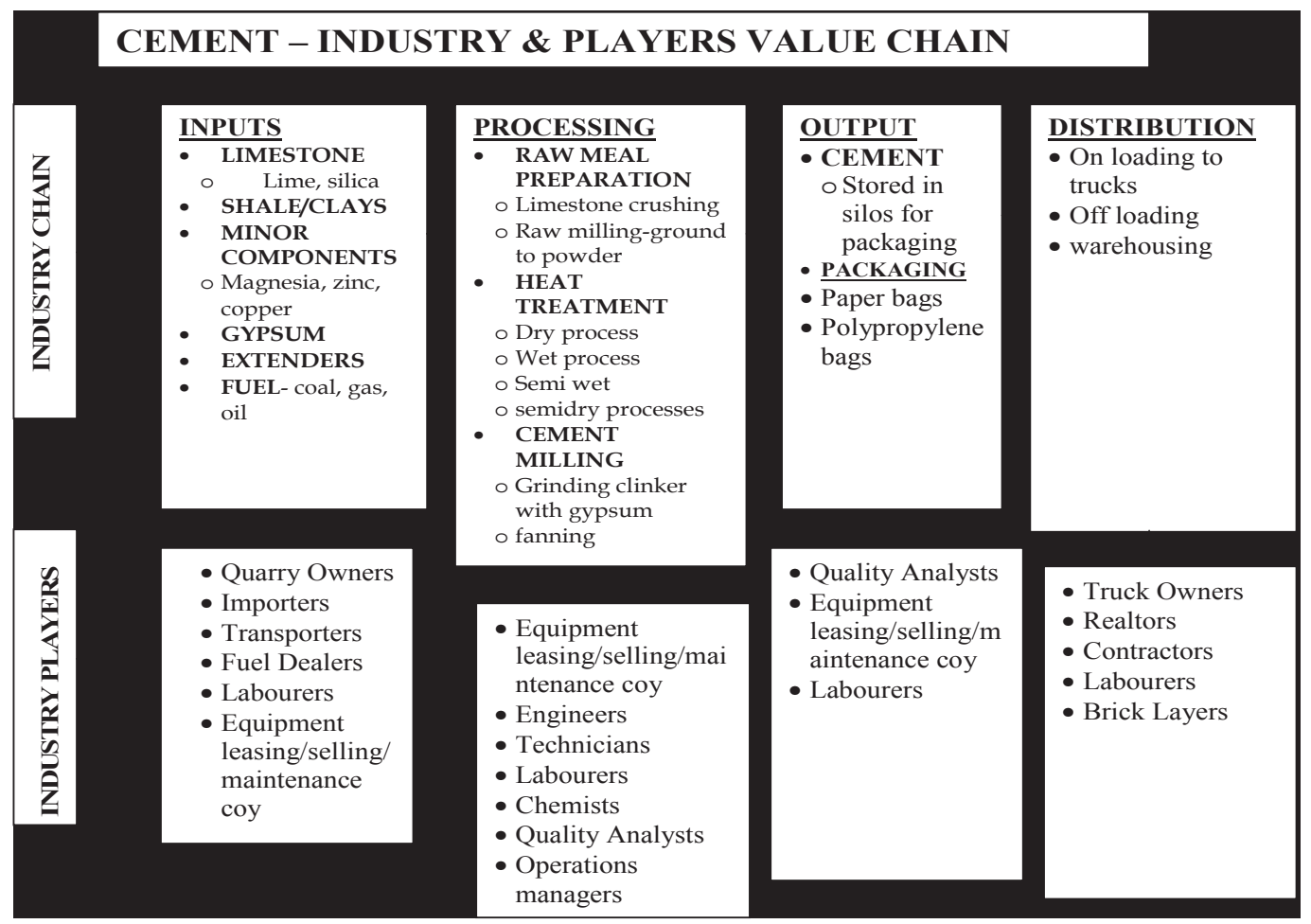

Nevertheless, owing to the numerous challenges in construction and cement sectors, the sectors are highly import dependent as some companies source their imported raw materials by importing them directly while others prefer to purchase their raw materials from locally based importers. Nevertheless, the building, construction and cement and by extension the solid mineral sector are central to the economic wellbeing of the country. The sectors influence economic activity in other major sectors and serves as barometer for the health of the economy. Although their contribution to GDP has been marginal, they have the potential to be a major growth driver, employing a significant proportion of the labor force. 


\section{Conclusion/Policy Recommendations}

Apparently, we are in a global era of "small government"-minimal government involvement in business cum investment activities. Given the failure of most of the past government solid mineral policy, when there was direct government involvement in the solid mineral exploration; there is a need for the government's role to be more of that of an open market -oriented and private sector led economy. Hence, the role of the government in the development of the solid mineral sub sector should be that of a facilitator / regulator and not that of the drivers of growth in this sub sector. Hence, the government is expected to create a conducive macroeconomic cum socioeconomic environment, which will facilitate trade investment (foreign and domestic) in the solid mineral sector and also enhance competitiveness in the sector. Moreover, the government should encourage domestic investors to invest in the solid mineral sector. Also, other macroeconomic trends such as inflation and interest rates will also need to be under check. In the same vein, government fiscal policy (tariffs and tax system) should be favorable to industries in the sub sector. Specifically, other government policy actions should include:

i. Encourage Private Sector Participation: The primary strategy should be to make the private sector the key to the development of the solid mineral sector. A database cum report on investment opportunities in this sector should be made accessible to both domestic and international investors.Ordinarily, the private sector is expected to take the lead in the in the development of the industrial sector. Hence, it should play a leading role in local sourcing or raw material, manpower development, technological innovation and adoption and support for research and development in the solid mineral sector. Thus, the private sector is expected to : -(a) ensure competitiveness in the solid minerals sector, create the necessary environment for achieving high productivity in the sector and dominate investment in the sector.

ii. International Awareness: Government's efforts should be directed at drawing international awareness to investments and business prospects in the solid mineral sector in Nigeria. Currently, the investment environments in Nigeria are skewed only toward oil / energy related sectors. Also, important is the fact that most of the investors that can finance huge scale solid mineral exploration are foreign investors.

iii. Infrastructural Development: this is important if any meaningful Foreign Direct Investment is to be attracted to the solid mineral sub sector. As earlier pointed out, the role of the government is to create the enabling environment and not to be in charge of the business sector and thus stimulate growth of investment and business. Thus government should focus on the improving infrastructure such as power supply, good roads amongst pothers as this will encourage more foreign investors, who have the requisite finance and expertise to contribute to the development of the solid mineral sector.

iv. Manpower Development: from the forgoing analysis, is evident that solid mineral development has a very high prospect for job creation in Nigeria. To enhance this further, investors should be required to promote on the job training for young school leavers especially for in SME solid mineral related jobs. There should also be a strict adherence to labour and standards. Importantly, the use of foreign employees in such sectors should be limited or curtailed.

v. Promote Raw Material Supply: Private investors should be encouraged to explore andprocess raw materials locally for use in the solid mineral development sector. Also, there is need to support geological surveys to explore new areas for mineral development.

vi. The adoption of best practices: The adoption of best practices and environment- friendly production techniques will go a long way in preserving the environment and sustaining the exploration of solid minerals in Nigeria.

vii. Welfare of host communities/Community Development Service: the promotion of the welfare of the host communities is also essential to in the overall development of the solid mineral sector. This is a lesson that has to be learnt from the crises that most times engulfed the oil producing areas, owing to the abandonment of the welfare of the host communities. Hence, the private sector should be encouraged to employ the use of skilled and unskilled labour available in the in the host communities. Thus, there is a need for the sector to promote community service through the provision of medical, educational agricultural recreational and other infrastructural facilities within the location of mining extraction areas.

viii. Timely Review of Policy: the evolving nature of the solid mineral industry, the failure of previous solid mineral development policy and the dynamics of the global market it serves means that there is a need for timely review of government solid mineral development policy taking cognizance of changes in standards, technology, markets and other matters that may arise from its implementing these policies. 


\section{References}

Central Bank of Nigeria Annual Statistical Bulletin Various Issues

Douglas O, Kemedi V, Okontal and Watts M (2004)“Oil and Militancy in the Niger delta: Terrorist Threat or another Columbia?" Niger Delta Economies of Violence Working Paper, No. 4

Land Use Act of the Federal Republic of Nigeria (1978); Chapter 202 Laws of the Federation of Nigeria 1990.

National Bureau of Statistics, (NBS) National Living Standard Survey NLSS (2004)

National Bureau of Statistics (NBS) Harmonised Living Standard Survey (2010)

National Bureau of Statistics (NBS) AnnualStatistical Bulletin Various Issues

Xavier S, Martin and A. Subramanian (2003); "Addressing the Natural Resource Curse: An illustration from Nigeria". NBER Working Paper No. 9804

Sachs, J.D and Warner, A.M, (1995)"Natural Resource Abundance and Economic Growth," Working Papers 517a, Harvard - Institute for International Development.

The Nigerian Minerals and Mining Act of 1999 
